\title{
NATIVE LAND RIGHTS AND NORTHERN DEVELOPMENT
}

\author{
PETER A. CUMMING*
}

In this article, the author continues his discussion of the question of native rights previously dealt with in (1973) 11 Alta. L. Rev. 238. He first discusses court developments. in the field of native rights since May, 1972. He pays particular attention' to the Nishga Case, the James Bay Development Case, and the Caveat Case in the Northwest Territories. He points out the effect that these decisions on the question of native title will have on Canadian society and urges that legislative action be taken to solve the problem. In the second part of his paper, the author deals with what he considers to be the main issues to be considered in any native land claims settlement. With a view to the rapid changes taking place in Northern Canada and their effect on native culture and society, he suggests the approach to be followed in land claims settlement. The settlement he stresses must both allow some native retention of land ownership while at the same time providing com. pensation for lands taken and an opportunity for the natives to participate in the management of the "New North". He insists that a compromise satisfactory to both the interests of natives and non-natives is possible and sets forth a proposal which, in his opinion, meets his criteria. Only through an approach resembling the suggested approach can the natives both preserve their culture and identity and at the same time integrate into the mainstream of Canadian society.

\section{RECENT COURT DEVELOPMENTS IN RESPECT TO THE QUESTION OF NATIVE TITLE}

The Federal Government, in a departure from Canadian history and law, had expressly stated in 1969 that native land rights, apart from those as part of treaty rights, would no longer be recognized.1 The native peoples, in seeking redress for the loss of their lands and traditional rights, have had to pursue their claims through the only forum available, the courts. It is useful to review briefly three major court cases.

The non-treaty Indian Nishga nation of British Columbia sought a declaration through court action that their native title had never been extinguished in respect of a large land area in the Nass River Valley of British Columbia. The British Columbia Court of Appeal in its decision declared that the Royal Proclamation of 1763 did not apply to British Columbia and further, that there could be no judicial recognition of native title in the absence of legislative or executive "recognition" of such title. ${ }^{2}$ The Nishga Tribe appealed to the Supreme Court of Canada and a decision was rendered January $31,1973 .^{3}$ The court held for the defendant, British Columbia. However, due to the nature of the judgments rendered, there was not a decision for the defendant on the merits.

This case was the most important court decision to that time in respect to native title. The Nishga case was heard by only seven justices,

\footnotetext{
- Professor of Law, Osgoode Hall Law School of York University. The writer emphasizes he speaks only for himself in this article, his views are not necessarily representative of those of any native organization, and his views are only tentative.

1 Department of Indian Affairs and Northern Development, Statement of the Government of Canada on Indian Policy (1969) [hereinafter referred to as the White Paper on Indian Policy].

2 Calder v. Attorney-General (1971) 13 D.L.R. (3d) 64, (1970) 74 W.W.R. 481 (B.C.C.A.).

a Calder v. Attorney.General [1973] S.C.R. 313.
} 
rather than the full nine member court usual in a case of such importance. Mr. Justice Hall, with Justices Laskin and Spence concurring, decided on the merits in favour of the Indians. Mr Justice Judson, with Justices Martland and Ritchie concurring, found on the merits for the defendant, British Columbia. The seventh Justice, Mr. Justice Pigeon, held for the defendant, but simply on a procedural basis.

As a result, the substantive issue as to whether the Nishga have native title remains unresolved by the court, as it does for all native peoples in Canada pursuing such claims. ${ }^{4}$ This would include the approximately 13,000 Inuit and many of the non-treaty Indians and Métis in the Northwest Territories. It would also include the approximately 7,000 treaty Indians there, if they can still assert an unsurrendered native title.

The controversy first ensuing from this decision often missed the point that the court is the least appropriate forum for dealing with native title. Litigation is expensive, time consuming, and abounds with technical uncertainties. Even if the Nishga were successful in their court action, further litigation would be necessary. First, further litigation would be required to resolve the question of the precise incidents of native title, as the question of the legal content of native title has not been resolved by the courts in Canada, and the Nishgas' action sought only a declaration that native title exists. Second, litigation would necessarily ensue to determine the conflicts as between native title and other, competing land users. Third, there would have to be litigation to determine if compensation were payable in those instances where native title existed but had been expropriated.

It seems obvious that these issues are best determined and resolved by legislation rather than by litigation. The questions involved cannot easily be answered on a yes or no basis, which is the only approach a court can take. The issues are such that they can only really be resolved to the satisfaction of all through a negotiated, fair, settlement which requires a political and legislative approach and solution. Suppose the court were to find that the Nishgas were successful on all counts. Although such a decision would not necessarily mean giving the country back to the Indians to the extent that the rest of society thought that this tended to be the effect of the court's decision, Parliament might act by way of expropriating legislation to cut back upon the court's decision in the perceived interests of the general Canadian society. On the other hand, if a court were to find that the Indians did not have any legal claim, the matter would certainly not have been fairly resolved. A factual situation remains-the Indians have traditionally used and occupied certain lands and waters. It would mean continuing representations to Parliament to enact legislation to reverse the court's decision. It would also mean continuing conflicts between the native peoples and competing land users until a legislative settlement was achieved.

Because of the stance of the Trudeau government in June, 1969 the only avenue open to native peoples has been to consider seeking protection of their rights through the courts. However, the simple truth is that Canadian law should recognize native title. This is so even if a court

- See generally Lysyk, The Indian Tille Question in Canada: An Appraisal in the Light of Calder, (1973) 51 Can. Bar Rev. 450. 
were to hold that native peoples' occupation of lands does not meet the formal criteria for title within the present Canadian legal system. The uncontested fact in the Nishga case was that the Nishgas had always occupied the lands in issue. Common sense and justice suggest that this factual situation be recognized within the legal regime. Therefore, the appropriate process for settlement of aboriginal rights is through political and legislative action. Parliament can, of course, change the law to accord with the needs of the factual situation in the best interests of all of Canadian society. ${ }^{5}$

In the days following the Nishga case, Prime Minister Trudeau told the Nishgas that he was impressed with the minority judgment and stated "perhaps you have more legal rights than we thought you had when we did the white paper". 6 Both the Conservative and New Democratic parties were calling upon the Government to recognize aboriginal rights and enter into a legislative settlement. Individual members of parliament for the opposition parties took a fairly strong position in favour of recognition. ${ }^{7}$ Given the minority Government situation, the Prime Minister was under considerable pressure.

Fortuitous from the standpoint of timing, on February 14, 1973, the Yukon Native Brotherhood presented its proposal to the Prime Minister for negotiation and settlement of the land claims of the more than 5,000 non-treaty Indians and non-status Indians of the Yukon. ${ }^{8}$ The Prime Minister, whose representatives had met with Indian leaders and had considered the proposal privately over the preceding week, warmly embraced the proposal and agreed to set up the requested negotiating committee "with great haste". 9

Thus, on February 14th, the Government in effect reversed its position in respect to native title, although without any formal recognition thereof. Although the Yukon proposal did not specifically ask for a settlement of its claims on a basis of native title, this was implicit in the proposal. A settlement of the claims of the Yukon native peoples is some considerable time away. However, whatever the legal niceties, the simple agreement to negotiate implied a recognition of some rights on the part of the native peoples, and a fair and reasonable settlement of claims based upon those rights.

The reasons were unclear as to why the Trudeau Government refused prior to February 14, 1973 to recognize aboriginal rights. There had been nebulous references to the view that such recognition might amount to 'giving the country back to the Indians'. Perhaps Mr. Trudeau's concern stemmed from his fear of assisting separatism in Quebec, for he had said: ". . . some of us are also sorry about the Plains of Abraham but we don't ask for compensation about that . . ."10 He failed to realize that the aboriginal rights question is not one of sovereignty. Moreover, at the time of the fall of New France, the British fully recognized the property rights of French settlers, as well as the property rights of the native peoples through the Royal Proclamation of

\footnotetext{
5 See Cumming. Native Rikhts and Law in an Age of Protest, (1973) 11 Alta. L. Rev. 238 at 256.

- Referred to in an article by Professor Cumming, Toronto Globe \& Mail. February 21, 1973, at 8.

: Id.

* Yukon Native Brotherhood, Together Today for Our Children Tomorrow; A Statement of Grievances and an Approach to Settlement by the Yukon Indian People: Prepared for the Commissioner on Indian Claims and the Government of Canada (1973).

9 Cumming, supra, n. 6.

to Speech given in Vancouver, British Columbia, August 8, 1969.
} 
1763. ${ }^{11}$ In any event, as Parliament has complete control of any legislative settlement of native title, nothing is really being given away through the recognition of such rights and the negotiation of a fair settlement.

There are two other important cases presently before the courts which relate to the question of native title.

The approximately 7,000 treaty Indians of the Northwest Territories have sought to lodge a caveat, in respect to lands traditionally used and occupied, with the Registrar of Titles of the Land Titles Office for the Northwest Territories. The Indians assert the literal wording of the treaties does not accord with the true agreement or understanding reached at the time of the signing of the treaties and that there has not been any legally effective surrender of their title.

In a decision given September 6, 1973,12 the Supreme Court of the Northwest Territories held in favour of the Indians in respect to the issue as to whether a caveat could be lodged, Mr. Justice Morrow saying: ${ }^{13}$

That notwithstanding the language of the two Treaties there is sufficient doubt on the facts that aboriginal title was extinguished that such claim for title should be permitted to be put forward by the caveators.

However, the court stayed the filing of the caveat pending a possible appeal, and the Federal Government has given notice of appeal.

The Superior Court of Quebec in a decision November 15, 1973 14 allowed petitioners representing some of the approximately 3,700 Inuit and 5,600 Cree Indians of the James Bay area of Quebec and interlocutory order of injunction against the James Bay Development Corporation and others in respect to the James Bay hydro electric project, already under construction. On November 22, 1973, the Court of Appeal for Quebec suspended the lower court's injunction until determination of the appeal in respect thereto. On December 21, 1973, the Supreme Court of Canada (by a 3:2 decision) refused leave to appeal to the petitioners in respect to the suspension order.

Therefore, the appeal in respect to the interlocutory order of injunction must be heard before the Court of Appeal. This appeal will, whatever the outcome, if leave is given, as seems probable, be appealed to the Supreme Court of Canada. Then, a final hearing on the merits for a permanent injunction must be heard by the Superior Court, whose decision will also be subject to the above appeal process.

If the Quebec Indians and Inuit are ultimately successful in court, undoubtedly the Government of Quebec will expropriate, probably through a specific piece of legislation. This will again possibly result in court action on the arguable assertion that the Province of Quebec does not have the constitutional power to expropriate native title. ${ }^{15}$

"It appears that there was a concerted effort, at the time of the conquest, to preserve the property rights of the French-Canadian colonists. British leaders, such as Attorney-General Edward Turlow and Solicitor-General Alexander Wedderburn, made statements to the effect that the colonists should be able to maintain their own laws to the greatest extent possible. The Quebec Act of 1774 permitted the retention of French civil law, and thus "embodied a new sovereign principle of the British Empire: the liberty of non-English people to be themselves". See 1 Burt, The Old Province of Quebec 166-181 (1968).

12 Re Paluette's Application to File a Caveat [1973] 6 W.W.R. 97 (N.W.T.S.C.).

13 Reasons for judgment, supra, n. 12 at 148.

14 Chief Robert Kanatewat et al. v. The James Bay Development Corporation et al. (as yet unreported).

15 By 8. 91(24) of the B.N.A. Act, the Federal Government has the competence to legislate in respect to "Indians, and Lands reserved for the Indians". The question then is, can a province expropriate property interests falling within a federal sphere of power, for purposes within the legislative competence of a province by $\mathbf{s}$. 
Again, there could be a multiplicity of court action, including a petition for an interlocutory order of injunction in the first instance. If this complex constitutional issue were decided in favour of the native peoples, the Federal Government would then have to decide whether it would meet Quebec demands to expropriate and if so, on what terms. Finally, even if the Federal Government did expropriate, there is an argument that native title in the James Bay area has received recognition and protection by the British North America Act and, therefore, even the Federal Government could not pass "expropriating" legislation which sought to deny that there is any native title. ${ }^{16}$ Therefore, court action could result from an attempted expropriation by the Federal Government, depending upon the approach taken by the Federal Government.

This article does not deal with the many legal issues, and only provides a brief synopsis of the major recent cases. However, three points are obvious from this discussion. First, in Calder ${ }^{17}$ there was a strong dissent recognizing native title, and in both the caveat case in the Northwest Territories ${ }^{18}$ and the James Bay case ${ }^{19}$ the trial courts' decisions, although both turn directly upon subsidiary or preliminary issues, suggest the petitioning native peoples may well have successful claims on the merits.

Second, the path of litigation has been the only recourse open to the native peoples, but it is a very complex and unsuitable approach to the fundamental problems and concerns. Even with successful litigation, there is the power of government to expropriate, although nice constitutional questions may arise in this regard.

Third, the only fair and ultimately successful approach to the root problems and concerns can come about through a political and legislative solution.

\section{THE PROSPECTS AND PRINCIPLES IN RESPECT TO A SETTLEMENT OF LAND CLAIMS IN THE NORTHWEST TERRITORIES}

In its White Paper in June, $1969,{ }^{20}$ the Federal Government had set forth a position of denying native title to non-treaty Indians and Inuit. This posture was maintained as recently as the Pipeline Guidelines of June, 1972.21 However, on August 8, 1973, the Government issued a new and encouraging policy statement saying that it "is prepared to negotiate" with non-treaty Indians and Inuit on the basis of their "tradi-

\footnotetext{
92 of the B.N.A. Act, when the expropriation would affect the very status of the native peoples, as they have an autchthonous culture, that is, their identity is intimately tied to the lands and waters they have traditionally used and occupied? Two of the many cases pertinent to this question of overlapping jursidiction are Charlie Cardinal v. The Attorney.General of Alberta (unreported as yet), a decision of the Supreme Court of Canada given June 29, 1973, and British Columbia Power Corporation Ltd. v. The Attorney.General of B.C. (1963) 44 W.W.R. 65, 47 D.L.R. (2d) 633. For a discussion of the last mentioned case, and of the issue generally, see La Forest, Natural Resources and Public Property Under The Canadian Constitution 174-182 (1969).

16 See the reasons for judgment of Morrow $J$, in the Northwest Territories Caveat case, supra, n. 12 at $36,37$. where he discusses the unique history of Kupert's Land and the transfer thereof by the Hudson's Buy Com. pany to Canada. Justice Morrow's remarks are pertinent as well in respect to the James Bay area as this territory historically was also part of Rupert's Land.

17 Supra, n. 3.

18 Supra, n. 12.

19 Supra, n. 14

20 Supra, n. 1.

2 Government of Canada, The Expanded Guidelines for Northern Pipelines, (1972). See also Canadian Arctic
} Resources Committee, Statement on Guidelines for Northern Pipelines, (1972). 
tional interest in lands". ${ }^{22}$ There are potential problems in the vague language and stipulated conditions of the August 8 statement. However, at long last the Government had at least said positively that it is prepared to negotiate. The Honourable Jean Chrétien, Minister of Indian Affairs and Northern Development, deserves considerable credit for this reversal in policy, and significant new initiative.

Moreover, the Government is actively funding native organizations in researching their land claims so as to allow the organizations to make proposals for a settlement in respect thereto. At the same time, one must look back with regret at the unfortunate expenditure of energy by native peoples over the past four years in the necessary struggle to gain recognition of rights. This has been the unavoidable preoccupation, rather than the important downstream questions as to how to settle claims based upon those rights.

The August 8 statement does not deal with the land claims of the treaty Indians in the Northwest Territories. The 7,000 treaty Indians assert there has not been a surrender of their native title and that the literal treaties do not accord with the true agreements at the time of treaty-making. As already discussed, the treaty Indians have sought to protect their claims through seeking to file a caveat and litigation in this regard is presently before the courts.

What of the future? What are the prospects of a land claims settlement in the north?

What continues to surprise me in my readings and travels in the north is the realization of the tremendous rapidity of change. Viljalmur Stefansson in his second expedition to the Arctic from 1908 to 1912 was meeting Inuit communities which had never before had contact with a white person. ${ }^{23} \mathrm{He}$ records that the Inuit civilization, stone-age in technology, was superbly functional and truly magnificent from the standpoint of culture and values. ${ }^{24}$ The late Mr. Justice Sissons regarded the Inuit as the people "par excellence".25

Few Canadians realize that many Inuit are experiencing within a single life-term the tremendous cultural transformation from a tribal community to industrial society. It is trite to state that all Canadians find confusion in the multiplicity of forces present due to rapidly accelerating technological and social change. As one contemporary historian has said in speculating upon the transformation of culture, "One can say almost anything about human culture now and it will be true, for everything is going on at once". ${ }^{26}$ This observation of general society is that much more true in respect to the experience of the Inuit, and northern native peoples generally.

A paradoxical tragedy is that while contemporary Canada could benefit a great deal from a healthy exposure to the values of native peoples, the inexorable forces of the technological society today threaten their very cultural existence.

The far north is entering a new phase of impact due to the dictates of non-native society. The first phase of economic activity arising from

\footnotetext{
22 Department of Indian Affairs and Northern Resources. Statement made by the Honourable Jean Chretien, Minister of Indian Affairs and Northern Development on claims of Indian and Inuit People (August 8, 1973).

${ }^{23}$ Stefansson, My Life with the Eskimo 173 (1962).

"Id.

2"Sissons, Judge of the Far North (1968).

26 Thompson, At the Edge of History IX (1971).
} 
outside influence was the 19 th century whaling industry, which ended about 1910. Then the fur economy came into full bloom, together with the ascendancy of the Hudson's Bay Company in the high Arctic. The era of the fur trader is now ending. ${ }^{27}$

With the oil discoveries in Prudoe Bay in 1965 and the subsequent exploration activity in the Mackenzie Delta, followed by that in the Arctic Islands, a third phase of change due to the needs of the nonnative economy has begun. The industrial economy appears to be around the corner, whether the oil and gas of the soon-to-be producing fields is delivered by pipeline, railway, airplane, tanker, or different combinations.

This brief and simplified view of the far north does not mean to overlook the impact of other important forces such as Christianity, the Dew Line in the 50's, and more recently, the non-native educational system. What is being emphasized is that, in my opinion, the incipient industrial era will be at least as traumatic a force as the collective impact of all those forces and changes experienced by native society to date.

The industrial economy is bringing profound changes. Some are already obvious. I was present at the Inuit Coppermine Conference in July, $1970^{28}$ at which time a central issue to those present was the intended exploration activity upon Banks Island. This was the firstever national conference of Inuit from across the north, and was truly a momentous occasion. Everyone sensed the magnitude of the forces being thrust upon the far north, and that for the first time the land base, the integral element of the autochtnonous culture, was significantly threatened. ${ }^{29}$ It is essential for the non-native person to realize that the very unique, essential, element of native culture is the intense relationship to the natural environment and to the extent that such relationship lessens, there is a corresponding diminution of cultural identity.

On my first trip to Inuvik in July, 1972, I was struck by the fact that the Pacific Western jet was required to 'hold' for about ten minutes due to a traffic jam above the airport caused by small planes and helicopters, most of which were undoubtedly engaged in the service of exploration activities. I thought of Stefansson who, in his travels by foot and boat sixty years before, at one point received a six month old message that a plane had crossed the English Channel for the first time! ${ }^{30}$ The 1973 annual meeting of the Inuit Tapirisat of Canada was held at Baker Lake in August. It was only thirty-two years ago that the first white woman, Anne Morrow Lindbergh, visited Baker Lake, on her famous trip. ${ }^{31}$ The airplane has truly been the vanguard of industrial technology in the north.

All of this brings us to the present and central question. What of the future? The first realization is that the land claims settlement, or absence thereof, is going to affect profoundly thousands of native people, their children and their children's children, for generations to come, and indirectly affect significantly all of Canadian society. It is the one opportunity for a new relationship between native and non-native society.

\footnotetext{
27 See generally Pryde, Nunaga: My Land, My Country (1972).

28 Indian-Eskimo Association of Canada, Coppermine Conference of Arctic Native People, July 14-18, 1970.

${ }^{2 y}$ See generally. 3 Usher. The Bankslanders: Economy and Ecology of a Frontier Trapping Community (1970).

30 Supra, n. 23.

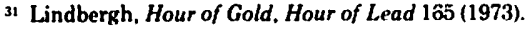


A settlement must be made, and many must be directly or indirectly involved in the process of determining a settlement within a context of apparently continuing rapid development. First, there are the native peoples and their communities, and the Federal Government. Also involved are the Territorial Government, the petroleum and mining industry, and the general public. On the periphery, there will be numerous groups emphasizing particular points of interest, for example, those concerned with environmental protection, energy policy and foreign ownership.

All of these groups are present in a dynamic process in respect to the Northwest Territories in which change through exploration and development activity is taking place more quickly than reasonable response can be attempted. Ideally, there would have been a temporary freeze upon exploration activities and development until comprehensive planning could have taken place in respect to all facets of development, not only in respect to land rights, but also such important matters as overall land-use planning, ecological and game preserves, national parks, and energy policy.

The truth is that there has really been an absence of meaningful advance planning by government in respect to the impending changes taking place in the north. Events have controlled government decisionmaking. Government has not controlled events in any meaningful way. This is not to direct fault specifically at any particular individual or government. There has been a coherent, well-planned and articulated, "northern vision". The events and issues are such as to tax the imagination and energy of any society. However, on most counts, Canada appears to be wanting as compared with other countries faced with similar problems and opportunities. For example, the United States imposed a five-year freeze prior to the passage of the imaginative Alaska Native Claims Settlement Act within a context of comprehensive land-use planning. ${ }^{32}$ First appearances suggest that even the Soviet Union, paradoxically for a monolithic society, seems to have integrated the native peoples in northern development and at the same time preserved a good deal of their cultural heritage. That is, there appears to be integration without assimilation. ${ }^{33}$

What about Canada? A reasonable settlement of land claims offers Government and non-native society the only significant opportunity to minimize the destructive aspects of northern development in relation to native peoples. Every Canadian is aware of the destruction rendered upon native peoples in southern Canada over the past century in the path of westward development. Those mistakes must not be repeated in the north. The opportunity through a land claims settlement must be realized and grasped with confidence.

It seems to me that a settlement of land claims (and any fundamentally different government policy) in respect to northern native peoples must include three essential elements. First, the people themselves must retain full ownership of considerable lands. Second, the people must have the right to share meaningfully in the material benefits of northern development, through compensation paid for the loss of some or all interests in those lands they have traditionally used and occupied but in respect to which they are not allowed to retain. Third, people must participate meaningfully in the process of orderly development.

32 Cumming, supra, n. 5i at 254.

${ }^{33}$ See generally. Shinkarev, The Land Beyond the Mountains: Siberia and Its People Today (1973). 
At this point in time, they are mostly on the receiving end of major decisions. Although some aspects of this third element of participation should not truly be regarded as part of a settlement, in that any government should always ensure that the affected citizenry participate fully in decisions, it must be considered as an important requirement of any new relationships for native peoples in respect to northern development. ${ }^{34}$ These, and other, elements of a land claims settlement will be discussed in greater detail shortly.

In my discussions with Inuit communities, the people emphasize maintaining their close relationship with the lands and waters traditionally used and occupied. At the same time, it is obvious to all that rapid changes are being forced upon the people and considerable development is going to take place. Therefore, the overriding problem is-to what extent, and how, can the native peoples influence the form of development, and to what extent can they control their destiny? At the same time, to what extent and how can the native peoples retain ownership and thereby preserve their traditional way of life or at least retain the closest possible relationship to their land, within a context of significant development?

This general consideration gives rise to two basic questions. The first important question in any settlement is-to what extent will Canadian society allow the retention of lands by native peoples? How much land can be retained, and what mechanisms can be used to accomplish this so that present and future generations of native peoples can continue to retain as much of these lands as possible?

Furthermore, to the extent changes are inevitable and development proceeds, it is clear that the native people should and wish to be involved in that development on both an ownership and management capacity. 'The people are not prepared to just be employees always taking direction from non-natives. They cannot be simply labourers, or alternatively welfare recipients. The second important question then is-how can the native peoples participate as owners and managers in development through a settlement?

The native peoples' culture and identity is based upon an intimate relationship with their lands and waters. An autochthonous culture, the people are truly part of the very lands they occupy. Their land is not regarded by them as a marketable commodity simply because it provided their traditional livelihood, with a cash payment through a sale seen as providing a substitute for physical needs. Their lands and waters are an integral part of their total being. To the extent that relationship is compromised, they lose their identity. Perhaps this is inevitable to some considerable extent, given the apparent attitudes and values of the dominant, non-native society. But the people do not want to sell their lands, and thus themselves and their heritage, for money. They do not want to give up their lands as part of a settlement.

In Alaska, the native people received a settlement whereby they retained forty million acres of land (about 10\% of Alaska) and received money as compensation for the taking of the remainder. ${ }^{35}$ However, the peoples' shares in the corporations which own the retained lands can be sold to non-natives, and the lands taxed, after twenty years. ${ }^{36}$ By then

"Cumming, supra, n. 5 at 243, 247. See also. The Hawthorne-Tremblay Report, A Survey of the Contemporary Indians of Canada: A Report on Economic, Political, Educational Needs of Policies, (ed. H.B. Hawthorne 196667).

3. Cumming, supra, n. 5 at 255 .

36 Id. 
the native peoples may well be wealthy Alaskans, but they will have lost a great deal of their identity as native people. Perhaps in some, relatively minor, ways the people will be better able to preserve some aspects of their traditions and culture. For example, they might use the monies received through a settlement to better teach young people native languages and traditions. However, their life style will be that of the wage economy and industrial society, the antithesis of the autochthonous culture.

The retention of identity and pride of native peoples is directly related to the degree of retention of ownership of lands by them as part of a settlement in Canada of their land claims.

A land claims settlement can also provide that the native people will share the economic benefits of development. This can be done through royalty mechanisms. Also, they must participate in the management of development, with a two-fold effect. First the advice of native people will result in more orderly development with greater respect for the natural environment. Second, through helping to manage development, the native people can develop the knowledge, skills, education, and experience similar to non-natives. Perhaps some day a native person will be manager of Imperial Oil's northern program. Such a person might have only a vague notion of how to hunt and trap, but he would be obviously well-equipped to survive in the non-native world. If the dominant society will not allow the natural environment to remain, with the result that traditional native society is diminished, then there must be meaningful opportunity within the new, displacing, society.

But, I emphasize, the native people are not happy about losing their lands and thus their life-style and values in exchange for simply a white life-style and values. The people do realize there must be some 'tradeoff,' because they do not live in a world where the choice is left simply to them. Surely there can be an acceptable 'middle point' whereby the native peoples and non-native society can mutually benefit. Yet the Government's statement of August 8, while vague, seems to emphasize consideration of a settlement whereby there is a voluntary surrender of native title in exchange for monetary benefits. The Government appears to wish to channel negotiations on a basis of the primary thrust being one of lands exchanged for monies. Such an approach, if it is intended, would be a grave mistake. A simple transfer of monies, even on the basis of being compensation for the extinguishment of rights rather than a handout, would only intensify rather than ameliorate the fundamental problem. The main reason for failure in native and nonnative relationships in Canada, historically, and at present, has been, on the one hand, the emphasis upon destroying native person identity, and on the other hand, paternalistically isolating the native person from the mainstream of Canadian society through denying true equality of opportunity. The native people can only take their rightful place within Canadian society if, and when, these critical errors in policy are realized and remedied. The settlement of land claims offers not only a significant, but the only opportunity in the north to make the required fundamental shift in approach in native and non-native relationships.

The native peoples want to retain their lands, but realize the practical necessity for some compromise. But monetary compensation is an 
acceptable alternative only to the extent they are given no choice and their lands are, in effect, expropriated.

I think an acceptable mix of the necessary elements to a fair settlement is possible. The dilemma is not incapable of a reasonable solution. A settlement might provide for some reasonable maintenance of the traditional way of life, identity, and self-determination of the native peoples, and yet accommodate orderly development in such a manner as to maximize the benefits of northern peoples and resources for all Canadians.

A settlement might accomplish this by being on the following basis. First, the native peoples would retain ownership, with formal legal recognition, to considerable tracts of those lands traditionally used and occupied. The native peoples would own all the interests in respect to these tracts of lands.

Second, the native peoples would have special hunting rights in respect to all lands and waters in the Northwest Territories. Game management in the sense of game conservation would be the responsibility of the total society, with full participation by native people. However, only native people would have hunting rights in respect to the limited game supply. They would be the ones entitled to game utilization. A 'grandfather clause' could allow for existing non-native residents to retain their hunting privileges, even those that are in derogation of native rights, but these privileges would not be extended to newcomers.

Third, the native peoples would retain the underlying ownership interest in respect to those lands traditionally used and occupied but in respect to which they are not allowed to retain full title. In respect to these tracts of lands, existing petroleum permits and mining claims would remain, but the native peoples would be recognized as owners of the residual interests in the lands. However, all Canadians, through an appropriate royalty sharing and tax structure, would share in the financial benefits of development of these lands.

Fourth, financial compensation would be paid to the extent there has been, in effect, expropriation without compensation of valuable interests in lands traditionally used and occupied, and the traditional way of life has been, and will be, compromised.

Fifth, appropriate mechanisms would be devised to ensure participation by native peoples and their communities in the management of development activities, from the standpoint of both management of a given business enterprise engaged in exploration or development, and also environment protection.

What is the appropriate and acceptable combination of the suggested factors in a land claims settlement? Obviously, from both a quantitative and qualitative standpoint, the native peoples, government, and industry to the extent it is affected, would each do a 'cost/benefits' analysis in the negotiation process. But the approach of the government and industry must converge with that of the native peoples.

It must be realized that it is only through a settlement which emphasizes ownership and management that the native peoples can achieve the difficult two-fold goals of many Canadians, that is, preservation of their identity yet integration within the mainstream of Canadian society. Financial compensation is important but it can come 
mainly through ownership with continuing development over a period of time. To isolate the people from ownership of their lands and the management of development of the north, is to isolate them from both their identity and also the mainstream of society. They would be left in a vacuum which would only repeat the mistakes of the south and be immensely more costly, in both social and dollar terms, over the long run than a settlement based upon the suggested approach. 